\section{CONYERS HERRING TO RECEIVE 1980 VON HIPPEL AWARD}

The Materials Research Society is pleased to name Professor Conyers Herring, Professor of Applied Physics, Stanford University, as recipient of its annual Von Hippel Award for 1980. This prize recognizes outstanding accomplishment in the multi-disciplinary endeavor of materials research, and is intended to honor pioneers who have shaped our understanding of the various disciplines which comprise the study of materials. The prize was named after its first recipient, Arthur Von Hippel, emeritus Professor at the Massachusetts Institute of Technology, and consists of a $\$ 1,000$ award and decorative ruby crystal. Presentation of the prize and acceptance remarks by Dr. Herring will take place beginning at 5:30 p.m. Tuesday, November 18,1980 at the Special Awards Reception in the main ballroom of the Copley Plaza Hotel.

Conyers Herring has enjoyed a long and distinguished scientific career. $\mathrm{He}$ obtained his Ph.D. in Physics from Princeton University in 1937, and from 1937-1941 taught at MIT, Princeton, and the University of Missouri. During the years 19411945 he was a Member of Staff, Division of War Research, Columbia University. From 1946 to 1976 Dr. Herring was a Member of Technical Staff at Bell Laboratories, Murray Hill, New Jersey, and since then has been Professor of Applied Physics at Stanford University.

Professor Herring has had a profound and seminal influence on the development of Materials Science and Solid State Physics. His contributions to the understanding of solid surfaces underpin the entire fields of crystal growth, sintering, and plastic flow at high temperatures. He, together with J. K. Galt, realized and demonstrated that whiskers of high crystalline perfection would exhibit extraordinary mechanical properties. $\mathrm{He}$ has contributed importantly to our understanding of transport in semiconductors, and his work on exchange interactions in ferromagnetism is regarded as classic. Dr. Herring's sustaining concern with scientific and social responsibility is exemplified by his current chairmanship of the Committee for a Literature Survey of Nuclear Power, sponsored by the National Academy of Sciences.

All Symposia attendees are cordially invited to participate in honoring Conyers Herring by attending the 1980 Von Hippel Award Reception on Tuesday, November 18,1980 at 5:30 p.m. in the Copley Plaza Hotel Ballroom.

\section{MATERIALS RESEARCH SOCIETY GRADUATE STUDENT AWARD WINNERS NAMED}

The Materials Research Society has initiated a student award program to recognize outstanding performance and promise for future substantial achievement in materials research at the graduate level. Selection criteria and areas of research for award consideration may be found in the July 1980 MRS Newsletter. Each award consists of a fifty dollar cash grant, waiver of the annual meeting registration fee and, where applicable, a grant to substantially underwrite travel expenses required to attend the meeting.

Award presentations for 1980 will be made at the Von Hippel Award Reception (Tuesday, November 18, 1980, 5:30 p.m.) by Dr. Kathleen Taylor of General Motors Research Laboratories, to the following students:

- Perry R. Skeath

Stanford Electronics Laboratories

Stanford University

Stanford, California

Areas of research:

Semiconductor Interfaces

Synthetic Modulated Materials

- John G. Pepin

Materials Research Laboratories

Penn State University

University Park, Pennsylvania

Areas of Research:

Scientific Basis for Nuclear

Waste Management 